\title{
Reproductive traits in different Nile tilapia genetic groups
}

[Características reprodutivas em diferentes grupos genéticos de tilápia do Nilo]

A.C.F. Silva ${ }^{1}$, R.A.C. Corrêa Filho ${ }^{1}$, A.S. Ventura ${ }^{*}$, A.L. Nunes ${ }^{1}$, L.M. Laice ${ }^{1}$, R.P. Ribeiro ${ }^{2}$, C.A.L. Oliveira ${ }^{2}$, L.C. Almeida ${ }^{1}$, P.T.L. Barbosa ${ }^{1}$, J.A. Povh ${ }^{1}$

${ }^{1}$ Faculdade de Medicina Veterinária e Zootecnia - Universidade Federal de

Mato Grosso do Sul - Campo Grande, MS

${ }^{2}$ Universidade Estadual de Maringá - Maringá, PR

\begin{abstract}
The aim of this study was to evaluate the reproductive traits of the non-inbred and inbred AquaAmérica, GIFT and AquaAmérica $\times$ GIFTgenetic groups. Six fish from each genetic group were used $(2$ females: 1 male). Females were examined for the presence of eggs in their mouth at every four days, for 12 weeks. Reproduction occurred in all genetic groups (GIFT: 100\%; non-inbred AquaAmérica and AquaAmérica $\times$ GIFT: 75\%; inbred AquaAmérica: 50\%). Female weight, female standard length, total spawning weight, absolute fecundity, relative fecundity, spawn index and hatching rate did not differ significantly between the genetic groups. However, the non-inbred AquaAmérica variety showed lower values $(\mathrm{P}<0.05)$ for egg diameter $(2.4 \mathrm{~mm})$ and egg weight $(4.2 \mathrm{mg})$ and higher values $(\mathrm{P}<0.05)$ for relative number of eggs $(247.6$ eggs/g of egg) than GIFT (egg diameter: 2.8mm; egg weight: $5.7 \mathrm{mg}$; relative number of eggs: 175.4 eggs/g of egg) and AquaAmérica $\times$ GIFT (egg diameter: 2.8mm; egg weight: 5.9mg; relative number of eggs: 168.8 eggs/g of egg). In conclusion, the non-inbred AquaAmérica variety produces smaller, lighter eggs but a higher relative number of eggs than the GIFT variety and the AquaAmérica $\times$ GIFT cross; and inbreeding negatively affects spawning rate.
\end{abstract}

Keywords: AquaAmérica; Fish reproduction; genetic breeding; GIFT; Oreochromis niloticus

\section{RESUMO}

O objetivo deste estudo foi avaliar as características reprodutivas dos grupos genéticos AquaAmérica não endogâmicos e endogâmicos, GIFT e AquaAmérica $\times$ GIFT. Foram utilizados seis peixes de cada grupo genético (duas fêmeas:um macho). As fêmeas foram examinadas quanto à presença de ovos na boca a cada quatro dias, durante 12 semanas. A reprodução ocorreu em todos os grupos genéticos (GIFT: 100\%; AquaAmérica não endogâmica e AquaAmérica $\times$ GIFT: 75\%; AquaAmérica endogâmica: 50\%). Peso e comprimento padrão de fêmea, peso total de desova, fecundidade absoluta, fecundidade relativa, índice de desova e taxa de eclosão não diferiram significativamente entre os grupos genéticos. Entretanto, a variedade não endogâmica da AquaAmérica apresentou valores mais baixos $(P<0,05)$ para diâmetro do ovo $(2,4 \mathrm{~mm})$ e peso do ovo $(4,2 \mathrm{mg})$ e maiores valores $(P<0,05)$ para número relativo de ovos $(247,6$ ovos $/ g$ de ovo ) que GIFT (diâmetro do ovo: 2,8mm; peso do ovo: $5,7 \mathrm{mg}$; número relativo de ovos: 175,4 ovos $/ \mathrm{g}$ de ovo) e AquaAmérica $\times$ GIFT (diâmetro do ovo: 2,8mm; peso do ovo: $5,9 \mathrm{mg}$; número relativo de ovos: $168,8 \mathrm{ovos} / \mathrm{g}$ de ovo). Em conclusão, a variedade AquaAmérica não endogâmica produz ovos menores e mais leves, mas um número relativo maior de ovos que a variedade GIFT e o cruzamento AquaAmérica $\times$ GIFT; a consanguinidade afeta negativamente a taxa de desova.

Palavras-chaves: AquaAmérica, reprodução de peixe, melhoramento genético, GIFT, Oreochromis niloticus

Recebido em 16 de outubro de 2019

Aceito em 29 de janeiro de 2020

*Autor para correspondência (corresponding author)

E-mail: arlenesventura@gmail.com 


\section{INTRODUCTION}

Nile tilapia (Orechromis niloticus) was the most widely farmed aquaculture species in Brazil in 2018 , corresponding to $55.4 \%$ (400.3 thousand tons) of the total national fish production (Anuário..., 2019). This is the only aquiculture species for which a breeding program has been consolidated in the country, which has contributed to the marked increase in its production compared with other fish species.

In order for aquaculture productivity to increase, selectively bred fish varieties must be available for the productive sector (Bentsen et al., 2017). In fish, selective breeding can provide gains of 8 $12 \%$ per selection generation in well-established programs (Nguyen, 2016), possibly reaching up to $15 \%$ (Ponzoni et al., 2005, 2011). However, selective breeding for weight at harvest (the main goal of fish breeding programs) may compromise reproductive traits, as observed in 12 selection generations of the GIFT variety in Malasya (Trong et al., 2013). Moreover, selection may lead to increased inbreeding, affecting reproductive traits (Alexandru et al., 2014). These situations reinforce the importance of monitoring reproductive traits in selection generations aimed at weight at harvest.

Selective breeding of aquatic organisms is a recent technique in Brazil. The first record of a selectively bred organism was in 2002, when Nile tilapia variety Supreme (GenoMar Supreme Tilápia) was imported, with a focus on the exclusive sale of monosex individuals (Cyrino et al., 2004). The GIFT variety (Genetically Improved Farmed Tilapia) was later introduced in year 2005 (30 families), imported by the State University of Maringá (UEM), located in Maringá - PR, Brazil, in a partnership with the World Fish Center (Oliveira et al., 2012). This variety derived from a cross of four wild African varieties (Ghana, Egypt, Kenia and Senegal) to four domesticated Asian varieties (Israel, Singapore, Taiwan and Thailand) (Eknath et al., 2007). The Nile tilapia variety AquaAmérica is one of the most recently developed in Brazil. It was created in 2012 in Alfenas -MG (Oliveira et al., 2016), and has been marketed in Brazil since 2014. This variety was developed from GIFT-variety families produced at the State University of Maringá and crossed to the Nile tilapia varieties
Chitralala and Bouaké, introduced in 1996 and 1971, respectively (Garcia et al., 2017).

Researchers have examined the reproduction of Nile tilapia in the most varied experiments involving reproductive traits of selectively bred (Supreme and Premium Aquabel) and nonselectively bred (Chitralada) varieties (Almeida $e t$ al., 2013); establishment of genetic parameters for reproductive traits (fecundity and fertility) (Trong et al., 2013); evaluation of egg quality at different commercial hatcheries (Cuevas-Rodríguez et al., 2017); and determination of protein, energy (Oliveira et al., 2014; Bombardelli et al., 2017; Orlando et al., 2017) and vitamin C (Sarmento et al., 2018) levels to improve fecundity and fertility. However, there are no comparative studies on the most recently selectively bred varieties in Brazil analyzing reproductive factors, the effect of inbreeding on reproductive traits and the effect of crossing between different genetically improved varieties on reproductive traits.

Selective breeding can impair reproductive traits throughout generations, and this situation may be further aggravated in cases of greater increases in inbreeding. Crossing between different varieties may, however, be a solution to this problem. In this respect, it is important to analyze reproductive traits to determine the possible impacts of selection throughout generations in a breeding program on reproductive traits (Trong et al., 2013).

The aim of this study was to evaluate the reproductive traits of size, quantity and quality of eggs of the non-inbred AquaAmérica, inbred AquaAmérica, GIFT and AquaAmérica $\times$ GIFT genetic groups.

\section{MATERIAL AND METHODS}

The experiment was conducted at the Experimental Fish Farming Center at the Federal University of Mato Grosso do Sul (20³0'04.6”S, 54 $\left.36^{\circ} 37.8^{\prime \prime} \mathrm{W}\right)$, located in Campogrande - MS, Brazil, from September to November. All experimental procedures were approved by the Ethics Committee on Animal Use at UFMS (approval no. 902/2017 - CEUA, FAMEZ, UFMS).

Nile tilapia varieties AquaAmérica (second generation of selective breeding) and GIFT 
(seventh generation of selective breeding) were used in the experiment. The GIFT variety originated from the State University of Maringá (UEM) (2324'18.2'"S, 51 $\left.{ }^{\circ} 56^{\prime} 20.7^{\prime \prime} \mathrm{W}\right)$, located in Maringá - PR, Brazil. The AquaAmérica variety was acquired from the Breeding Center at the AquaAmérica company (2126'02.8”S, 46 '04'37.5”W), located in Alfenas -MG, Brazil. The selective-breeding program for the AquaAmérica and GIFT varieties developed in Brazil adopts the weight at harvest and filet yield of fish grown in net cages and hatcheries as selection criteria (Garcia et al., 2017).

The following genetic groups were formed for the evaluation: GIFT; inbred AquaAmérica (full siblings, $25.0 \%$ inbreeding of parents); noninbred AquaAmérica (without common ancestors up to the third generation and no common greatgrandfather - maximum inbreeding of $2.0 \%$ ); and a cross between the AquaAmérica (female) and GIFT (male) varieties.

The breeding fish were housed in four $15-\mathrm{m}^{3}$ net cages distributed in a $700-\mathrm{m}^{2}$ excavated pond. Each net cage housed six fish at the sex rate of two females for each male (Kubitza, 2011; Yoshida et al., 2015). Two-year-old fish of the non-inbred AquaAmérica (female: 1358.3 $\pm 637.2 \mathrm{~g}$; male: $1762.0 \pm 138.6 \mathrm{~g}$ ), inbred AquaAmérica (female: $1397.5 \pm 279.3 \mathrm{~g}$; male: $1568.0 \pm 141.4 \mathrm{~g}$ ), GIFT (female: $1110.0 \pm 70.7 \mathrm{~g}$; male: $1633.5 \pm 245.4 \mathrm{~g}$ ) and AquaAmérica $\times$ GIFT (female: $1433.3 \pm 293.8 \mathrm{~g}$; male: $1827.5 \pm 161.9 \mathrm{~g}$ ) groups were used.

The fish were captured individually and checked for the presence of eggs in their mouth. In the positive case, their mouth was washed using a wash bottle to remove the eggs, which were then collected in a plastic container (Yoshida et al., 2015). Subsequently, the number of the microchip corresponding to the spawned female was recorded. In all treatments, the presence of eggs was checked every four days to prevent the larvae from being born before collection (Almeida et al., 2013; Valentin et al., 2015). The period of analysis of reproductive traits was 12 weeks (84 days). The eggs from each female were placed in a 3-L cylinder-conical incubation tank with aeration and continuous water renewal $(7 \mathrm{~L} / \mathrm{s})$. The average water temperature in the incubation system was $26.0 \pm 1.0^{\circ} \mathrm{C}$.
The following variables were analyzed: female weight $(\mathrm{g})$, female standard length $(\mathrm{cm})$, total spawning weight $(\mathrm{g})$, egg diameter $(\mathrm{mm})$, egg weight (mg), absolute fecundity (number of eggs per spawning), relative fecundity (number of eggs per spawning/g of female weight), spawn index ([total egg weight per spawning in $\mathrm{g} / \mathrm{female}$ weight in $g]^{*} 100-\%$ ), hatching rate ([number of hatched larvae in the sample/total number of eggs and larvae in the sample]*100 - \%) and relative number of eggs (number of eggs/g of eggs). To determine egg diameter (larger diameter), 18 eggs from each female were analyzed under a microscope (Leika, $100 \mathrm{X}$ magnification). Egg weight was determined as the average of eggs present in a $1 \mathrm{~g}$ egg sample (1g of eggs/number of eggs in $1 \mathrm{~g}$ ), which was measured in triplicate. The total number of eggs to determine the absolute fecundity and relative fecundity was obtained by counting the number of eggs in a $1 \mathrm{~g}$ sample and multiplying this number by the total weight of eggs laid, also in triplicate. The number of eggs to determine the relative number of eggs was obtained by counting the eggs present in a $1 \mathrm{~g}$ sample, also performed in triplicate. Hatching rate was determined as proposed by Almeida et al. (2013), by counting 100 egg samples from each female, in triplicate.

The fish received an extruded feed $(32 \%$ crude protein, $6.5 \%$ ether extract, $4 \%$ crude fiber, $14 \%$ mineral matter and $88 \%$ dry matter), which was supplied at the rate of $1 \%$ of their live weight per day, in two daily quotas (served at $08 \mathrm{~h} 00$ and 16h00). Temperature $\left({ }^{\circ} \mathrm{C}\right)$, dissolved oxygen $(\mathrm{mg} / \mathrm{L})$ and water $\mathrm{pH}$ were measured using a multiparameter meter (YSI Professional Plus®).

The experiment was set up as a completely randomized design with four treatments (genetic groups: non-inbred AquaAmérica, inbred AquaAmérica, GIFT and AquaAmérica $\times$ GIFT hybrid) and four replicates (each female was considered an experimental unit). Assumptions of analysis of variance (ANOVA) were obtained by analyzing the results of other studies and applying Levene's test for homogeneity of variances. All dependent variables were analyzed by an ANOVA with one dependent variable (genetic group) followed by Student's t test to compare the least square means of genetic groups at the $5 \%$ significance level. Before the analyses, the percentage variables (spawn index and hatching rate) underwent angular transformation (Zar, 
2010). All analyses were performed using SAS statistical package version 2002.

\section{RESULTS}

At the start of the experiment, the water temperature was $26.9^{\circ} \mathrm{C}$. After one week, the temperature dropped to $21.6^{\circ} \mathrm{C}$ but started to rise again until reaching its peak in the entire experiment $\left(28.8^{\circ} \mathrm{C}\right)$. Over the following weeks, there were also variations, but of lower magnitude. The $\mathrm{pH}$ ranged from 7.7 to 8.5 during the entire experiment. Dissolved oxygen fluctuated from 4.0 to $8.1 \mathrm{mg} / \mathrm{L}$ throughout the experiment (Figure 1).

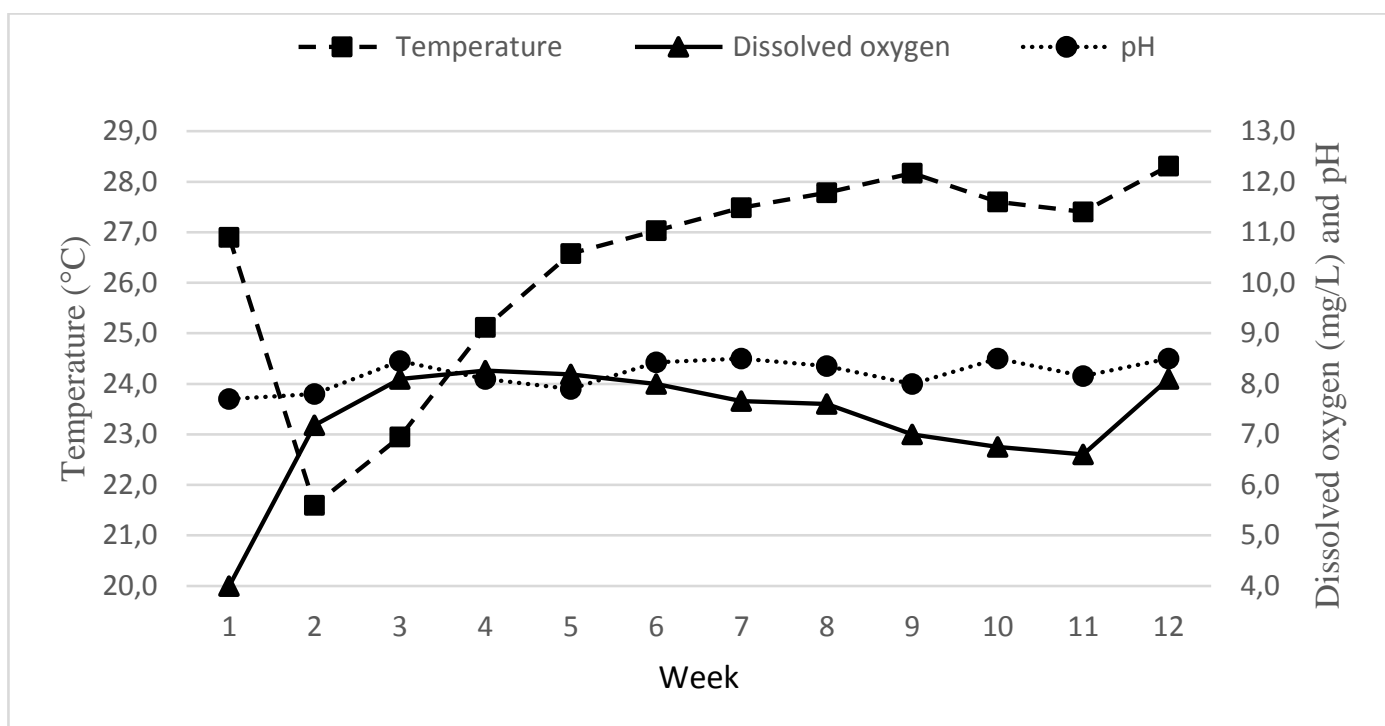

Figure 1. Water characteristics during the experiment conducted from September to November.

Reproduction occurred in all genetic groups. Three females $(75 \%)$ of the non-inbred AquaAmérica variety spawned (first week of September); three females $(75 \%)$ of the genetic group derived from the AquaAmérica $\times$ GIFT cross spawned (first week of September); four GIFT females (100\%) spawned (second week of September); and two females $(50 \%)$ of the inbred AquaAmérica variety spawned (last week of November). The only females to spawn more than once in the 12-week experimental period belonged to the AquaAmérica (one) and GIFT (two)groups.

Female weight and length did not differ significantly between the four genetic groups analyzed in this study. Likewise, total spawning weight, absolute fecundity, relative fecundity, spawn index and hatching rate did not differ significantly between the genetic groups (Table 1).

Egg diameter and egg weight were higher $(\mathrm{P}<0.05)$ in the GIFT $(2.8 \mathrm{~cm} ; 5.7 \mathrm{mg})$ and AquaAmérica $\times$ GIFT $(2.8 \mathrm{~cm} ; 5.9 \mathrm{mg})$ genetic groups than in the non-inbred AquaAmérica variety $(2.4 \mathrm{~cm} ; 4.2 \mathrm{mg})$. By contrast, the relative number of eggs was higher $(\mathrm{P}<0.05)$ in the noninbred AquaAmérica variety (247.6 eggs/g of egg) than in thegIFT (175.4 eggs/g of egg) and AquaAmérica $\times$ GIFT (168.8 eggs/g of egg) varieties (Table 1). 
Table 1. Least square means of reproductive performance traits in Nile tilapia females (Oreochromis niloticus) of different genetic groups evaluated over 12 weeks

\begin{tabular}{|c|c|c|c|c|c|c|}
\hline \multirow[b]{2}{*}{ Trait } & \multicolumn{6}{|c|}{ Genetic group ${ }^{2}$} \\
\hline & $\begin{array}{c}\text { Non-inbred } \\
\text { AquaAmérica }\end{array}$ & $\begin{array}{c}\text { Inbred } \\
\text { AquaAmérica }\end{array}$ & GIFT & $\begin{array}{c}\text { AquaAmérica } \\
\text { ×GIFT }\end{array}$ & $\begin{array}{l}\mathrm{CV} \\
(\%)\end{array}$ & $\begin{array}{c}\text { P- } \\
\text { value }^{3}\end{array}$ \\
\hline Female weight (g) & 1358.3 & 1397.5 & 1110.0 & 1433.3 & 27.9 & 0.802 \\
\hline Female SL $(\mathrm{cm})$ & 42.3 & 42.0 & 41.1 & 42.3 & 10.1 & 0.976 \\
\hline $\begin{array}{l}\text { Total spawning } \\
\text { weight }(\mathrm{g})\end{array}$ & 25.7 & 17.8 & 14.8 & 42.4 & 60.3 & 0.176 \\
\hline $\operatorname{LED}(\mathrm{mm})$ & $2.4^{\mathrm{b}}$ & $2.6^{\mathrm{ab}}$ & $2.8^{\mathrm{a}}$ & $2.8^{\mathrm{a}}$ & 5.6 & 0.016 \\
\hline Egg weight (mg) & $4.2^{\mathrm{b}}$ & $5.2^{\mathrm{ab}}$ & $5.7^{\mathrm{a}}$ & $5.9^{\mathrm{a}}$ & 10.4 & 0.016 \\
\hline Absolute fecundity & 6160.9 & 3738.5 & 2581.1 & 7084.3 & 63.5 & 0.275 \\
\hline Relative fecundity & 4.9 & 2.4 & 2.2 & 5.4 & 70.9 & 0.374 \\
\hline Spawn index $(\%)^{1}$ & 1.8 & 0.9 & 1.2 & 3.0 & 36.0 & 0.277 \\
\hline Hatching rate $(\%)^{1}$ & 99.2 & 96.8 & 98.5 & 93.0 & 7.2 & 0.226 \\
\hline RNE (eggs/g of eggs) & $247.6^{\mathrm{a}}$ & $194.9^{\mathrm{ab}}$ & $175.4^{\mathrm{b}}$ & $168.8^{\mathrm{b}}$ & 13.9 & 0.025 \\
\hline
\end{tabular}

Female SL: standard length of females (cm); LED: egg diameter (mm) (larger diameter); Absolute fecundity (number of eggs per spawning); Relative fecundity (number of eggs per spawning/g of female weight); Spawn index (\%) ([Total egg weight per spawning in $\mathrm{g} /$ Female weight in $\mathrm{g}]^{*} 100$ ); Hatching rate $(\%)$ ([number of hatched larvae in the sample/total number of eggs and larvae in the sample]*100); and RNE: relative number of eggs (number of eggs/g of eggs). ${ }^{1}$ Values result from the inverse transformation of angular transformation. ${ }^{2}$ Means of genetic groups followed by the same letter in the row do not differ statistically by Student's $t$ test at the $5 \%$ significance level. ${ }^{3} \mathrm{P}$-value of ANOVA.

\section{DISCUSSION}

Reproduction occurred in distinct forms across the Nile tilapia varieties, as also observed by Almeida et al. (2013). Only half of the females of the inbred AquaAmérica variety spawned, revealing a possible effect of inbreeding on reproduction, similarly to the findings reported by Alexandru et al. (2014). The non-inbred AquaAmérica variety produced smaller and lighter eggs but a higher relative number of eggs than the other genetic groups. However, this outcome did not influence hatching rate. This may be a consequence of selection for weight at harvest on that variety. These results suggest a need for monitoring reproductive traits in selectively bred varieties throughout selection generations to prevent the occurrence of losses in those traits.

Although the water temperature declined at the end of the first week, it remained within the range deemed adequate for tropical fish $\left(25.0\right.$ to $\left.32.0^{\circ} \mathrm{C}\right)$ as recommended by Boyd (1998), during most of the experiment. According to that author, the $\mathrm{pH}$ and dissolved oxygen concentration (except in the beginning of the first week) were also within the range considered adequate for tropical fish $(\mathrm{pH}$ : between 6 and 9; dissolved oxygen: above $5 \mathrm{mg}$ $\left.\mathrm{dL}^{-1}\right)$.
In Nile tilapia, reproduction is highly influenced by the water temperature, with values below the adequate range negatively affecting it (Almeida $e t$ al., 2013; Hui et al., 2014). The temperature remained at around $26^{\circ} \mathrm{C}$ during a large part of the experiment but dropped to $21.6^{\circ} \mathrm{C}$ at end of the first week, which possibly affected reproduction, particularly in the inbred AquaAmérica variety. Furthermore, in the GIFT (spawns recorded in the second week of October) and inbred AquaAmérica (spawns recorded in the last week of November) varieties, spawning occurred later than in the non-inbred AquaAmérica variety and AquaAmérica $\times$ GIFT cross (spawns recorded in the first week of September). This indicates that the GIFT and inbred AquaAmérica groups were more sensitive to the low temperature at the onset of the experiment, which reflected in a delayed start of spawning compared to the other genetic groups. Likewise, Almeida et al. (2013) observed that most females of different varieties (Supreme, Premium Aquabel and Chitralada) spawned (between 30 and 45\%) when the water temperature was adequate (near $30^{\circ} \mathrm{C}$ ). By contrast, when the temperature dropped to $25^{\circ} \mathrm{C}$, some varieties showed a more marked decline in spawning (Premium Aquabel, decreasing to less than $10 \%$ ) than others (Chitralada, decreasing to approximately $28 \%$ ). 
Upon reaching sexual maturity, Nile tilapia can spawn all year long provided that the water temperature is within the adequate range. Under favorable temperature conditions, it may spawn up to 8 to 12 times per year (Trewavas, 1983). In an optimum setting, spawning may occur every 21 days (Almeida et al., 2013); accordingly, at an adequate temperature, the species could spawn 0.7 to 1.0 times per month. During the experimental period (12 weeks), only one female of the noninbred AquaAmérica variety and two GIFT females achieved this proportion.

Reproductive frequency can be further increased by adopting the strategy of harvesting eggs directly from the mouth daily so that all females could be prepared to reproduce again soon after the first spawn. Moreover, factors such as diet (Oliveira et al., 2014; Bombardelli et al., 2017; Orlando et al., 2017; Sarmento et al., 2018), fish density in the reproduction net cages and environmental conditions (Yoshida et al., 2015) are essential to maximize spawning by females.

Female weight and standard length did not differ between the varieties, meaning that the size of the females in the different genetic groups did not influence the reproductive traits. Sexual maturity occurs later in selectively bred Nile tilapia varieties, as observed by Yoshida et al. (2015). Those authors found better reproductive traits (spawning rate and spawning frequency) in twoyear-old females (precisely the age of the fish used in the present study) compared to one-yearold fish. In non-selectively bred Nile tilapia varieties, reproduction starts earlier, as described in the studies by Cuevas-Rodrígues et al. (2017) and Sarmento et al. (2018), and reproductive rates are better at earlier ages (e.g.: 8 months) than at older ages (3 years) (Vanletin et al., 2015). This information is important in comparing reproductive traits between selectively bred and non-selectively bred varieties. Monitoring reproductive traits is an essential part of a breeding program, since there may be negative genetic correlations between these traits and selection for weight at harvest (Trong et al., 2013).

Although total spawning weight did not differ significantly across the genetic groups, the AquaAmérica variety showed the lowest values for egg diameter and egg weight, which led to a higher relative number of eggs in that genetic group compared to the others. It should be noted that the AquaAmérica variety produces a higher relative number of eggs, which is also higher than those observed in other selectively bred (156.0 eggs/g of eggs) and non-selectively bred (155 eggs/g of eggs) varieties (Almeida et al. 2013). Some researchers have reported that egg diameter (2.1 to $2.6 \mathrm{~mm}$ ) and egg weight (3.5 to $7.5 \mathrm{mg}$ ) may vary depending on the diet (Orlando et al., 2017; Bombardelli et al., 2017; Sarmento et al., 2018). However, in the present experiment, the observed variation was due to genetics, since all groups received the same feed and were farmed in the same environment. In this regard, future analyses of the development of larvae, post-larvae and fingerlings of the AquaAmérica variety are important to determine whether a smaller egg size may affect the development and survival in those phases.

Absolute fecundity (AF) was not influenced by the genetic groups. The observed values for this variable were higher than those found by Almeida et al. (2013) in other selectively bred (1544.6 to 2143.2 eggs/spawning) and non-selectively bred (1658.5 eggs/spawning) varieties. Similarly, relative fecundity (RF) was not influenced by the genetic group. In the current study, the RF values were similar to those reported by Almeida et al. (2013) (3.7 to 4.3 eggs/g female weight). In Nile tilapia, AF and RF are highly variable according to the environment and the diet, as shown in the works of Oliveira et al. (2014) (AF between 2860.3 and 3757.3 eggs/spawning; RF between 3.3 and $4.7 \mathrm{eggs} / \mathrm{g}$ of female weight); Valentin et al. (2015) (AF between 902.7 and 1174.6 eggs/spawning; RF between 1.1 and $5.7 \mathrm{eggs} / \mathrm{g}$ of female weight); Orlando et al. (2017) (AF between 348.0 and 467.8 eggs/spawning; RF between 5.1 and 6.6 eggs/g of female weight); and Sarmento et al. (2018) (AF between 622.6 and 1191.8 eggs/spawning; RF between 3.6 and 10.1 eggs/g of female weight).

Spawn index was also not influenced by the evaluated genetic groups. Likewise, Almeida et al. (2013) did not observe significant differences (between 2.2 and 2.6\%) in three Nile tilapia varieties (Supreme, Premium Aquabel and Chitralada). It is noteworthy that the high coefficients of variation observed for spawn index, absolute fecundity and relative fecundity warrant a larger sampling size in future studies on reproduction in Nile tilapia for those traits, 
considering that such variation is natural for those variables, which are naturally unstable.

The similar results for hatching rate across the genetic group show that egg quality is not compromised regardless of the variety, cross between varieties and inbreeding level. Almeida et al. (2013) also did not observe variations in hatching rate between different varieties, which shows that the main difference between varieties is found in spawning percentage and quantitative reproductive traits (e.g., egg diameter, egg weight and relative number of eggs), given that the qualitative reproductive traits were similar between the evaluated groups.

Considering that there may be a negative correlation between selection for weight at harvest and reproductive traits (Trong et al., 2013), these traits should be monitored at every selection generation. Additionally, evaluating the development of larvae and post-larvae and fingerlings is an essential measure to ensure that their development and survival are not compromised by the selection performed in breeding programs.

\section{CONCLUSION}

The genetic groups showed distinct reproductive traits. The highest spawning percentages were observed in the GIFT genetic group and the lowest in the inbred AquaAmérica group. The non-inbred AquaAmérica variety produces a higher relative number of eggs, although smaller and lighter than those produced by the GIFT and AquaAmérica $\times$ GIFT genetic groups.

\section{ACKNOWLEDGMENTS}

This study was financed in part by the Coordenação de Aperfeiçoamento de Pessoal de Nível Superior - Brasil (CAPES) Finance Code 001, the Fundação Universidade Federal de Mato Grosso do Sul - UFMS/MEC - Brazil, and the Ministério de Ciência e Tecnologia, Ensino Superior e Técnico-Profissional (MCTESTP) Moçambique.

\section{REFERENCES}

ALEXANDRU, V.B.; GABRIEL, C.; LUCIAN, I. et al. Morphological abnormalities as a result of inbreeding in controlled reproduction in Oreochromis niloticus, Linnaeus, 1757. J. Biotech., v.185, p.18-36, 2014.

ALMEIDA, D.B.; COSTA, M.A.P.; BASSINI, L.N. et al. Reproductive performance in female strains of Nile tilapia, Oreochromis niloticus. Aquacult. Int., v.21, p.1291-1300, 2013.

ANUÁRIO PeixeBR da piscicultura 2019, São Paulo: PeixeBR, 2019.146p.

BENTSEN, H.B.; GJERDE, B.; EKNATH, A.E. et al. Genetic improvement of farmed tilapias: Response to fivegenerations of selection for increased body weight at harvest in Oreochromis niloticus and the further impact of the project. Aquaculture, v.468, p.206-217, 2017.

BOMBARDELLI, R.A.; GOES, E.S.R.; SOUZA, S.M.N. et al. Growth and reproduction of female Nile tilapia fed diets containing different levels of protein and energy. Aquaculture, v.479, p.817823, 2017.

BOYD, C.E. Water quality for pond aquaculture. Auburn: Auburn University, 1998. 37p.

CUEVAS-RODRÍGUEZ, B.L.; GARCÍAULLOA, M.; HERNÁNDEZ-LLAMAS, A. et al. Evaluating quality of Nile tilapia (Oreochromis niloticus) eggs and juveniles from different commercial hatcheries. Lat. Am. J. Aquat. Res., v.45, p.213-217, 2017.

CYRINO, J.E.P.; URBINATI, E.C.; FRACALOSSI, D.M. et al. Tópicos especiais em piscicultura de água doce tropical intensiva. Jaboticabal: Sociedade Brasileira de Aquicultura e Biologia Aquática, 2004. 533p.

EKNATH, A.; BENTSEN, H.B.; PONZONI, R.W. et al. Genetic improvement of farmed tilapias: composition andgenetic parameters of a synthetic base population of Oreochromis niloticus for selective breeding. Aquaculture, v.273, p.1-14, 2007. 
GARCIA, A.L.S.; OLIVEIRA, C.A.L.; KARIM, H.M. et al. Genetic parameters forgrowth performance, fillet traits, and fat percentage of male Nile tilapia (Oreochromis niloticus). J. Appl. Genetics., v.58, p.527-533, 2017.

HUI, W.; XIAOWEN, Z.; HAIZHEN, W. et al. Joint effect of temperature, salinity and $\mathrm{pH}$ on the percentage fertilization and hatching of Nile tilapia (Oreochromis niloticus). Aquacult. Res., v.45, p.59-269, 2014.

KUBITZA, F. Tilápia: tecnologia e planejamento na produção comercial. Jundiaí: Acqua Supre, 2011. 316p.

NGUYEN, N.H. Genetic improvement for important farmed aquaculture species with a reference to carp, tilapia and prawns in Asia: achievements, lessons and challenges. Fish Fish., v.17, p.483-506, 2016.

OLIVEIRA, C.A.L.; RIBEIRO, R.P.; STREIT JUNIOR, D.P. et al. Melhoramentogenético de peixes, uma realidade para piscicultura Brasileira. Panorama Aquicultura, v.130, p.38-47, 2012.

OLIVEIRA, C.A.L.; RIBEIRO, R.P.; YOSHIDA, G.M. et al. Correlated changes in body shape after Fivegenerations of selection to improvegrowth rate in a breeding program for Nile tilapia Oreochromis niloticus in Brazil. J. Appl. Genet., v.57, p.487-493, 2016.

OLIVEIRA, M.M.; RIBEIRO, T.; ORLANDO, T.M. et al. Effects crude protein levels on female Nile tilapia (Oreochromis niloticus) reproductive performance parameters. Anim. Reprod. Sci., v.150, p.62-69, 2014.

ORLANDO, T.M.; OLIVEIRA, M.M.; PAULINO, R.R. et al. Reproductive performance of female Nile tilapia (Oreochromis niloticus) fed diets with different digestible energy levels. Rev. Bras. Zootec., v.46, p.1-7, 2017.
PONZONI, R.W.; HAMZAH, A.; TAN, S. et al. Genetic parameters and response to selection for live weight in thegIFT strain of Nile tilapia (Oreochromis niloticus). Aquaculture, v.247, p.203-210, 2005.

PONZONI, R.W.; NGUYEN, N.H.; KHAW, H.L. et al. Genetic improvement of Nile tilapia (Oreochromis niloticus) with special reference to the work conducted by the WorldFish center with thegIFT strain. Rev. Aquacult., v.3, p.27-41, 2011.

SARMENTO, N.L.A.F.; MARTINS, E.F.F.; COSTA, D.C. et al. Reproductive efficiency and egg and larvae quality of Nile tilapia fed different levels of vitamin C. Aquaculture, v.482, p.96-102, 2018.

TREWAVAS, E. Tilapiine fishes of thegenera Sarotherodon, Oreochromis and Danakilia. London: British Museum (Natural History), 1983. $583 \mathrm{p}$.

TRỌNG, T.Q.; ARENDONK, J.A.M.V.; KOMEN, H. Genetic parameters for reproductive traits in female Nile tilapia (Oreochromis niloticus): II. Fecundity and fertility. Aquaculture, v.416-417, p.72-77, 2013.

VALENTIN, F.; NASCIMENTO, N.F.; SILVA, R.C. et al. Maternal age influences on reproductive rates in Nile tilapia (Oreochromis niloticus). Rev. Bras. Zootec., v.44, p.161-163, 2015.

YOSHIDA, G.M.; OLIVEIRA, C.A.L.; KUNITA, N.M. et al. Reproduction performance of female Nile tilapia under different environments and age classes. Acta Sci. Anim. Sci., v.37, p.221-226, 2015.

ZAR, J.H. Biostatistical analysis, 5.ed. Upper Saddle River: Prentice-Hall/Pearson, 2010. 944p. 